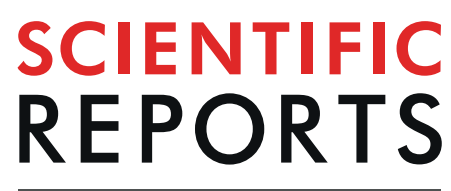

natureresearch

\title{
OPEN Author Correction: Quantitative proteomic analysis of enhanced cellular effects of electrochemotherapy with Cisplatin in triple-negative breast cancer cells
}

\author{
Lakshya Mittal $\mathbb{D}$, Uma K. Aryal $\mathbb{D}$, Ignacio G. Camarillo, Rodrigo M. Ferreira \& \\ Raji Sundararajan
}

Correction to: Scientific Report https://doi.org/10.1038/s41598-019-50048-9, published online 26 September 2019

The Acknowledgements section in this Article is incomplete.

"L.M. is grateful to the partial support by the Purdue Polytechnic Institute Dean's award GRA - FY16. Publication of this article was funded by Purdue University Libraries Open Access Publishing Fund. We thank Victoria Hedrick of the Purdue Proteomics Facility for support in LC-MS/MS data collection and for critical reading of the manuscript. All the mass spec experiments were performed at the Purdue Proteomics Facility, Bindley Bioscience Center. The Q Exactive Orbitrap HF and UltiMate 3000 HPLC system used for LC-MS/MS analysis were purchased from funding provided by the Purdue Office of the Executive Vice President for Research and Partnership. We thank Alexis A. Musleh for help in maintaining the cell cultures and assistance in experiments and Vishak Raman for useful discussions. The authors are grateful to Dr. Richard J. Kuhn's lab for the use of spectrophotometer, Dr. Chun-Ju Chang's lab for the Nanodrop ${ }^{\mathrm{TM}}$, Dr. Ourania M. Andrisani's lab and Dr. Emily C. Dykhuizen's lab for their qPCR machines."

should read:

"L.M. is grateful to the partial support by the Purdue Polytechnic Institute Dean's award GRA - FY16. Publication of this article was funded by Purdue University Libraries Open Access Publishing Fund. We thank Victoria Hedrick of the Purdue Proteomics Facility for support in LC-MS/MS data collection and for critical reading of the manuscript. All the mass spec experiments were performed at the Purdue Proteomics Facility, Bindley Bioscience Center. The Q Exactive Orbitrap HF and UltiMate 3000 HPLC system used for LC-MS/MS analysis were purchased from funding provided by the Purdue Office of the Executive Vice President for Research and Partnership. We thank Alexis A. Musleh for help in maintaining the cell cultures and assistance in experiments and Vishak Raman for useful discussions. The authors are grateful to Dr. Richard J. Kuhn's lab for the use of spectrophotometer, Dr. Chun-Ju Chang's lab for the Nanodrop ${ }^{\mathrm{TM}}$, Dr. Ourania M. Andrisani's lab and Dr. Emily C. Dykhuizen's lab for their qPCR machines. The authors are grateful to Prof. Morris Levy for his excellent edits."

\footnotetext{
(c) (i) Open Access This article is licensed under a Creative Commons Attribution 4.0 International License, which permits use, sharing, adaptation, distribution and reproduction in any medium or format, as long as you give appropriate credit to the original author(s) and the source, provide a link to the Creative Commons license, and indicate if changes were made. The images or other third party material in this article are included in the article's Creative Commons license, unless indicated otherwise in a credit line to the material. If material is not included in the article's Creative Commons license and your intended use is not permitted by statutory regulation or exceeds the permitted use, you will need to obtain permission directly from the copyright holder. To view a copy of this license, visit http://creativecommons.org/licenses/by/4.0/.
}

(C) The Author(s) 2019 